\title{
Evaluation of Cu Phonon Frequency Spectrum Under High Pressure Using Different (EOS)
}

\author{
Zena W. Al-Abady Adnan M. Al-Sheikh \\ Department of Physics \\ College of Science \\ Mosul University
}

(Received 15 / 10 / 2009 ; Accepted 10/5/2010 )

\begin{abstract}
In the present work evaluation of effect of high pressure on phonon frequency spectrum for copper has been performed by using different equations of state (EOS) and evaluating lattice vibrations frequencies shift and variations of mode density under high pressure. Variation of Grüneisen parameter under high pressure has been considered in our calculations.

\section{لحتسلبطف التردد الفونوفي النحلس تتهت الضظط الهالي بأستخدلمaعادلات حالةمختلة}

\section{الملغص}

مَ في هذا البهث لحتسلب تأثير الضغط العالي علىطف التردد الفونوني للنطلس من خلل لحتسب

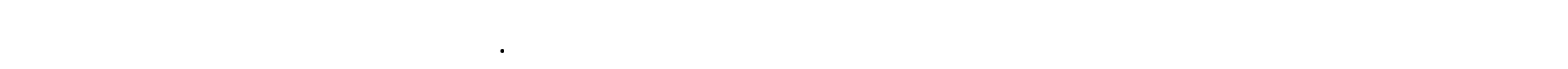
معادلات حالة والأخذ بالاعتبار تغير معالمل كرونيشين تهت الضغط العالي.
\end{abstract}

